Małgorzata Rygielska

\title{
Rytmy czasu, meandry pamięci. O poezji Bogusławy Latawiec
}

Jasne jest, że pisarz musi wziąć się za bary z czasem, a to, jak sobie $z$ tym poradzi, świadczy o mistrzostwie jego rzemiosła.

E.T. Hall, Taniec życia. Inny wymiar czasu

Bogusława Latawiec jest z całą pewnością poetką znaną, cenioną i lubianą, choć jej twórczość nie doczekała się do tej pory całościowego, monograficznego opracowania ${ }^{1}$, co wydaje się tym bardziej zaskakujące, że właściwie każdy tom jej wierszy zostaje niemal natychmiast zauważony przez krytykę literacką i wiernych czytelników. W liryce Latawiec zachwycać, a jednocześnie zaskakiwać może (nawet przy znajomości często wskazanych wprost lub zasugerowanych inspiracji) świeżość ujęcia problemów, z którymi człowiek boryka się od zawsze, wydany na pastwę czasu, zanurzony jednocześnie w naturze i kulturze, wychylony ku wieczności. Tę odkrywczość zapewnia nie tylko siła wyobraźni, ale też niezwykłe wyczulenie na słowo (mówione i pisane), na dźwięk i obraz, $\mathrm{w}$ dużej mierze podzielane nie tylko $\mathrm{z}$ poetyckimi mistrzami Latawiec (takimi jak Julian Przyboś czy Tymoteusz Karpowicz), ale

1 Najnowszą, unikatową propozycją jest tom Bogustawa Latawiec - portret podwojony o charakterze monograficznym, zawierający omówienia twórczości Latawiec oraz materiały z jej prywatnego archiwum [Grądziel-Wójcik, Łuszczykiewicz 2016]. 
i podwajane - w życiu oraz w twórczości - z Edwardem Balcerzanem. Związki człowieka z innymi ludźmi, współistnienie z roślinami i zwierzętami, a także nieuchronna czasowość wszelkich działań, również artystycznych, to ważne, powracające motywy liryki Latawiec.

Niezwykła dyscyplina językowa, umiejętne wyzyskanie środków formalnych wraz z ścisłym połączeniem obrazu z dźwiękiem to cechy wyróżniające tej poezji, jej differentia specifica, widoczna (i słyszalna) jeszcze bardziej, gdy wiersze zestawi się z twórczością prozatorską autorki Zegarów nie do zatrzymania (od powieści poprzez opowiadania aż po różne formy biograficznych i autobiograficznych narracji). Szczególnym przykładem może być tutaj Gęstwina [Latawiec 2001], zbiór bardzo osobistych esejów, z których każdy, bez względu na to, jakiego tematu dotyczy, zamyka się wierszem - to skłaniać może do pytania o to, jak przedstawiają się relacje między językiem i rzeczywistością w prozie, a jak w poezji, generującej dodatkowe sensy, zawieszonej zawsze i nieuchronnie pomiędzy Wahrheit und Dichtung, prawdą oraz zmyśleniem (Ezra Pound [1981: 167] pisał niegdyś, że „Wielka literatura jest po prostu językiem naładowanym znaczeniem - do ostatecznych granic"; ta specyficznego typu ekonomia szczególnie uwidaczania się w liryce).

Więzi literackie oraz pozaliterackie, sploty życiorysów, lekturowe fascynacje - wszystko to dodatkowo oświetla poezję Latawiec. Pozwala też, oddając głos samej autorce i jej wierszom, ukazać wielopłaszczyznowość i złożoność tej liryki, która jest zarazem wyjątkowa (bo można mówić o jej oryginalnym i rozpoznawalnym idiomie), a także po ludzku uniwersalna (ponieważ dotyka tego, co ważne dla nas wszystkich). Jednym z najważniejszych dla tej poezji wątków są związki człowieka z czasem: bycie, trwanie, przemijanie, niezbywalne uwikłanie w czasowość swoją i świata - zostało to już dostrzeżone przez badaczy i krytyków [por. m.in. Michałowski 1999: 81-83; Delaperrière 2006: 135; Jakubowska-Ożóg 2012: 276-278).

Edward Terence Hall, znany amerykański antropolog, który zwrócił uwagę na wagę kulturowego kontekstu oraz wykazał, jak duże znaczenie mają odmienne rytmy czasowe w różnych kulturach (podobnie jak sposoby postrzegania czy organizowania przestrzeni), pytając o to, czego może nauczyć nas literatura, wyznał: 
„Wychowałem się, polegając na literaturze jako źródle informacji o tym, co ludzi absorbuje". Wykazał też, że dla wielu pisarzy i filozofów - wśród których wymienił między innymi Henri Bergsona, Marcela Prousta, Jamesa Joyce’a, Aldousa Huxleya, Williama Faulknera, Thomasa Manna i Franza Kafkę - charakterystyczne jest dualistyczne, właściwe kulturze zachodniej (w ujęciu Halla północnoeuropejskiej oraz amerykańskiej), postrzeganie czasu: stąd też w ich dziełach pojawiały się często podziały na czas „indywidualny i uniwersalny, $[\ldots]$ artystyczny i materialistyczny, $[\ldots]$ oddzielenie i stopienie, teraźniejszość i przyszłość, patrzenie z zewnątrz do środka i ze środka na zewnątrz, życie i sztuka, $[\ldots]$ chwilowość i wieczność” [Hall 1999: 150-151]. Próby „radzenia sobie z czasem" podejmowali i podejmują także poeci - również dla nich jest to jednocześnie test artyzmu oraz rzemiosła. Oczywiście, istotny okazuje się zarówno przekaz zawarty w ich twórczości, jak i sposób jego formułowania.

W poezji Latawiec jednym z najważniejszych wątków są właśnie związki człowieka z czasem: bycie, trwanie, przemijanie, niezbywalne uwikłanie w czasowość swoją i świata, a także w nie zawsze zrozumiały bieg historii. Co ciekawe, czas, jego przeżywanie i doświadczanie, również (choć nie tylko) w wymiarze historycznym, są szczególnie istotne $\mathrm{w}$ dziełach prozatorskich autorki Całego drzewa zdania, w dużej mierze autobiograficznych, choć jednocześnie ukazujących tło historyczno-kulturowe konkretnych - opisywanych wprost lub zaledwie aluzyjnie przywoływanych - wydarzeń. Anna Legeżyńska [1990: 113] pisała o Ciemni: „Książka Bogusławy Latawiec jest nade wszystko powieścią o problemie, do którego dorastamy wszyscy; książką o czasie”. Wydaje się jednak, iż to właśnie w liryce Latawiec problematyka czasu ujawnia się w całej swej złożoności i pełni.

Maurice Merleau-Ponty, podkreślając fundamentalną zależność między czasem a podmiotowością [por. Toadvine 2014: 19], przywołał jako motto rozważań o temporalnym uwikłaniu człowieka wieloznaczną frazę zaczerpniętą z Art Poétique Paula Claudela: „Le temps est le sens de la vie (sens: comme on dit le sens d'un cours d'eau, le sens d'une frase, le sens d'une étoffe, le sens de l'odorat)”. Jak zauważył tłumacz, pojawia się w niej „Nie dająca się oddać 
po polsku wieloznaczność francuskiego słowa sens”, fragment ten należałoby bowiem przełożyć: „Czas jest sensem (prądem, kierunkiem, zmysłem) życia (sens: tak jak mówi się o prądzie (sens) nurtu wody, sensie (sens) zdania, prawej i lewej stronie (sens) tkaniny, zmyśle (sens) powonienia" [cyt. za: Merlau-Ponty 2001: 431].

Można by te słowa wyzyskać również jako motto rozważań nad funkcją, znaczeniem i sposobami konceptualizowania czasu w poezji Latawiec. Nie chodzi bynajmniej o podążanie ścieżką wytyczaną przez autora Prozy świata i wskazywanie związków dzieł polskiej twórczyni z fenomenologią (choć i taka interpretacja byłaby możliwa, a nawet uzasadniona), ale o takie odczytywanie tej liryki, które ujawni swoiste dla niej oraz w jej obrębie ujmowanie czasu i czasowości. W wierszach Latawiec poszczególne metafory (nierozpatrywane w izolacji) budują bowiem szerszy i bardziej skomplikowany obraz: substancjalności czasu.

W jednym z pierwszych tomów poetyckich, Przestrzenie (1975), wydanym po zbiorach Otwieraja się rzeki (1965) i Całe drzewo zdania (1970), Latawiec wyodrębniła - oprócz wprowadzającego wiersza o incipicie „Mówię wprost...” i podrozdziałów Przestrzeń człowieka, Przestrzeń światła, Przestrzeń drewna całostkę Przestrzeń czasu. Została ona umieszczona pomiędzy pierwszym a drugim z wymienionych podrozdziałów, tak więc nawet na poziomie kompozycji zostały zasugerowane związki człowieka i czasu. Ich indywidualny wymiar sprowadzać się może do subiektywnego odczuwania czasu, w tym do postrzegania samego siebie w relacji do przeszłości. Powstały w Tuczepi i Poznaniu liryk Kamienie dalmatyńskie (z części Przestrzeń człowieka), który otwiera fragment

\footnotetext{
W kamieniu ciasno splecionym z żył i czasów

jest światło - tak przestronne - jak w pamięci, [Latawiec 1975: 21; por. 2015: 37]
}

objawia dojmującą świadomość nieuchronnego wpisania ludzkich losów w bieg historii: 
Czy z pochodniami tu biegli

głęboko wbitymi w noc

brocząc powietrzem?

[Latawiec 1975: 21]

Jednocześnie pojawia się tu przyzwolenie na osobiste przeżycia, niepowtarzalny puls autobiografii. Łącznikiem pomiędzy tym, co dziejowe, a tym, co współczesne (oddalone nie tylko w czasie, ale i przestrzeni) jest kamień - niemy świadek wydarzeń dawnych oraz obecnych. W tym utworze, podobnie jak w znajdującym się kilka kart dalej Rodowodzie, poszukuje się podobieństw i różnic pomiędzy członkami własnej rodziny, próbuje określić siebie względem przodków:

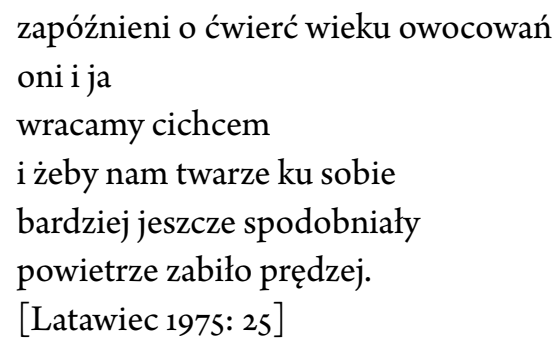

Przynależność rodową wyznaczają nie tylko więzy krwi, ale również związki z ziemią - z konkretnym miejscem bądź okolicą z której się wywodzimy, i z jej tworzoną przez ludzi historią. Nie bez powodu zaraz po tym liryku znajduje się kolejny, z taką samą datacją: Sandomierz - Poznań, XI. 73 r., zatytułowany Sandomierz mego ojca. Zapowiadają one część Przestrzeń czasu, nieuchronnie powiązaną z Przestrzenia człowieka - z przestrzenią zamieszkiwaną, oswajaną i uznawaną za swoją.

W Przestrzeni czasu znajdują się też wiersze już w tytule przywołujące konkretne miary czasu. W niektórych z nich wskazane są one wprost, jak na przykład w Nocy pamięci, Otwieraniu lat, Sekundzie jesieni, 1. I. 7or., w innych zaś metaforycznie, jak w Drodze do szkoły czy pięknym utworze miłosnym Iść w zasypianie. W jednym z nich pojawia się stwierdzenie: 
to wreszcie moment

kiedy zdołam udźwignąć całą

ciemność swojej pamięci

będąc na niej jak smuga pędzącej bieli.

[Latawiec 1975: 33]

Pamięć, a szczególnie ta autobiograficzna, pozwala nam odczuwać nasze życie jako ciągłość, rozpoznawać samego siebie w innym [por. Ricoeur 2003, 2008]. „Materiał zapisywany w pamięci autobiograficznej jest bardzo silnie związany z kontekstem i kontekst wyznacza ramy dla zrozumienia tego materiału”, a jednocześnie bardzo istotna przy konstruowaniu tej pamięci okazuje pamięć epizodyczna, dotycząca konkretnych doświadczeń jednostki, często silnie odczuwanych zmysłowo. Mogą nakładać się na siebie pamięć „okresów życia” (jak w Rodowodzie), „zdarzeń ogólnych” i „zdarzeń specyficznych” - relacje między nimi rozmaicie się wtedy zarysowują [Maruszewski 2005: 20, 59]. Sięganie w przeszłość może odbywać się na różne sposoby: retrospekcja wiąże się nie tylko z namysłem nad sobą, ale i umieszczeniem siebie w konkretnym momencie na linii czasu (jeśli odmierzany jest on przy pomocy narzędzi: zegarów, kalendarzy... ). Taka refleksja wymaga maksymalnego skupienia:

Otwieranie lat odbywa się w ciszy gdy niebo na wieku czarną skórą tak szczelnie że...

Nie aby od razu wejść pochylonymi plecami wprost w czas nie w jego zakurzone zegary lecz ręce zanurzyć po łokcie oprzeć się o godziny aż w liniach krwi wędrówce rok przegnie się gałęzią chłodnej kory nareszcie najbliższy.

[Latawiec 1975: 35] 
Ujawnia się tutaj nie tylko typowe dla większości kultur europejskich postrzeganie czasu, ale też rozziew pomiędzy jego mechanicznym mierzeniem a subiektywnie odczuwanym upływem. Hall [1999: 33] zauważy1: „W Świecie Zachodnim czas świecki wyznacza minuty i godziny, dni tygodnia, miesiące, rok, lata, dekady, wieki - jest to system całkowicie zrozumiały, przyjmowany za rzecz oczywistą, system wypracowany przez naszą cywilizację". W wierszu Latawiec wyzyskane zostaje podobieństwo dźwiękowe słów: „wiek” (jako jednostka czasu składająca się z lat) i „wieko” (pokrywa; która jednocześnie może być „ciężką pokrywą nieba" lub wiekiem trumny, otwieranym i zamykanym). Czas ujmuje się tu linearnie, biegnie on od jakiegoś początku do końca, dlatego też „przeszłość” mamy za sobą, za pochylonymi plecami: by wejść w minione lata, trzeba ruszyć wstecz na osi czasu, cofnąć się. Otwieranie lat może odbywać się w na dwa sposoby i dotyczyć zarówno tego, co minione (i już - w pewnym sensie - zamknięte), jak i tego, co dopiero nadejdzie. Dlatego mówi się niekiedy o (zapośredniczonym) dostępie do przeszłości oraz o rozpoczynaniu - otwieraniu - nowego roku, a więc tego, który będzie. Jeśli

[j]edną z ważniejszych konieczności życiowych jest władanie czasem, jest jego „zagospodarowanie” w związku z działaniami, mającymi na celu utrzymanie własnej egzystencji. Władanie czasu wymaga jego rachuby - choćby elementarnej, a rachuba możliwa jest dzięki organizacji czasu, polegającej na fragmentaryzacji continuum $[. .$.$] , [Zajączkowski$ 1988: 16]

to liryka Latawiec ujawnia, że żyjemy w co najmniej kilku rozmaitych rytmach czasowych, niekoniecznie koherentnych. Czas mierzalny można „obserwować”: wpatrywać się w ziarna piasku w klepsydrze, śledzić ruch wskazówek na tarczy zegara; czas subiektywny jednak niejednokrotnie plynie zupełnie niezależnie od niego, wolniej lub szybciej, zgodnie z rytmem krwi oraz przemianami natury [por. Dembińska-Pawelec 2010]. Wiemy, że istnieje „czas sakralny, świecki, metaficzyczny, fizyczny, biologiczny 
i zegarowy, ale nie bardzo zdajemy sobie sprawę z tego, jak się one mają do siebie i jak wpływają na nasze życie" [Hall 1999: 20-21]. Na nasze odczuwanie czasu, sposoby jego organizowania i postrzegania w istotny sposób wpływa kultura, w której żyjemy - wzorce kulturowe, a także mniej lub bardziej naznaczone subiektywnością rytmy osobiste i rodzinne. Ich wzajemne relacje są nierzadko bardzo skomplikowane, trudne do uchwycenia oraz opisania.

W Drodze do szkoty pojawia się wspomnienie chwil dzieciństwa i tętniące w nim rytmy, obrazowanie wyraźnie wspiera tu warstwa foniczna wiersza, dzięki czemu odliczanie czasu ma swój walor wizyjno-dźwiękowy (jak chociażby ledwo słyszalny odgłos zawiązywanych w pośpiechu wstążek przed pójściem na lekcje oddany przy pomocy ciszących, szeleszczących i bezdźwięcznych głosek):

Z chodników zerwał się nagle

gołąb w furkocie powietrza

czas

moich warkoczy

Jest gonitwą wstążek o poranku

szelestem tafty tuż przy uszach

poprzez coraz bliższy

idący od rynku

zegar kopyt

[...

Bicie dzwonu

odliczałam

po ich tbach

przeskakując

w biegu

ostatnie sekundy białego boiska

aż powietrze znieruchomiało po ósmym uderzeniu

i skrzydła dwóch bram jednocześnie

zatrzaśnięto

tuż przed moimi stopami.

[Latawiec 1975: 36-37] 
Wielość rytmów czasowych, w których żyje człowiek (cykl wegetatywny, cykle liturgiczne, kulturowo regulowane i wyraźnie od siebie odróżniane okresy codzienności oraz świętowania, rytmy pracy czy wypoczynku, wreszcie rytmy prywatne i osobiste), sprawia też, że czas wciąż odmierzamy na różne sposoby. Dzwony kościelne odzywają się o konkretnych godzinach, podobnie jak te w miejskim ratuszu; upływ chwil można odliczać stukotem końskich kopyt lub odgłosem własnych stóp poderwanych w pośpiechu do rytmicznego biegu. Czas staje się wtedy słyszalny - brzmienie jego różnych rytmów rozchodzi się w powietrzu, dźwięki własnego tętna i zewnętrznego tętentu, bicie dzwonów, odliczanie sekund nakładają się na siebie podobnie jak różne rodzaje czasu.

Mierzenie przestrzeni upływającym czasem (sformułowanie „trzy dni drogi stąd”; świadomość, że kilka uderzeń dzwonu wyznacza odległość od drzwi domu do szkolnego boiska), a czasu rozciągłymi w przestrzeni substancjami (na długo przed wynalezieniem zegarów mechanicznych przy pomocy wody, piasku, ale też spalających się powoli wykonanych z różnych materiałów świec) oraz wypowiadanymi na głos lub w myślach słowami (zazwyczaj posiadających swój własny rytm i doskonale znanych na pamięć modlitw lub powtarzanych od dzieciństwa wierszy) pomimo szybkiego rozwoju techniki i coraz nowszych technologii nie zanikają, choć współcześnie (czy bardziej niż kiedykolwiek wcześniej?) żyjemy poddani władzy zegara, dyktatom terminów, tabel, planów, bez ustanku nadchodzących powiadomień na elektronicznych urządzeniach, które w założeniu miały wszak pomóc w sprawniejszej organizacji działań, lepszej organizacji (!) czasu i optymalizacji życia. Nie oznacza to jednak, że nie jesteśmy zanurzeni w kilku co najmniej rytmach jednocześnie. Wręcz przeciwnie. Latawiec śledzi te rytmy, obserwuje, opisuje - w prozie i w poezji - każdorazowo dobierając najbardziej adekwatne środki artystyczne: tropy, metafory, hiperbole. Nie bez powodu też czas historyczny (silnie spleciony z autobiograficznym) najczęściej eksploruje w prozie [por. m.in. Latawiec 1989, 2003], a subiektywne odczuwanie czasu - w poezji.

To właśnie w liryce odkrywa się „ziemną duszę czasu” [por. Latawiec 2011: 11], jego zmienną gęstość, rozciągłość, materialność. Przeszłość niekiedy sama się objawia w nagłym olśnieniu, niekiedy 
natomiast próbujemy do niej docierać w akcie świadomego, bywa, że uporczywego, choć nie zawsze zakończonego sukcesem, „odpominania”. Z opisem takiego „poszukiwania straconego (?) czasu” spotykamy się w wierszu Ta sama ziemia z ziemią:

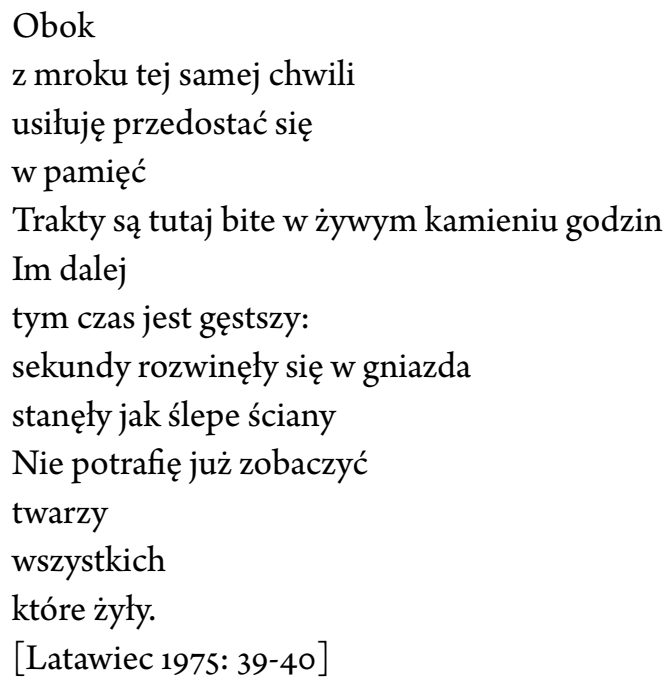

Metafora wspominania jako poszukiwania ścieżek dostępu, powracania znanym traktem do minionych wydarzeń - nośna w poezji i filozofii - wykorzystywana bywa współcześnie także w naukach przyrodniczych, neurobiologii oraz informatyce. Mówią o niej w poważnych rozprawach psycholodzy i literaturoznawcy [por. m.in. Draaisma 2006, 2009, 2012; Rydz 2011]. Jednak zarówno w refleksji naukowej, jak i w poezji Latawiec niejedyna to taka metafora. Skomplikowane procesy zapamiętywania oraz przypominania (sobie), wspierane przez rozmaite czynniki biologiczne i kulturowe, które pozostają ze sobą nierozerwalnie związane, wciąż pozostają nie tylko trudne do zbadania, ale też do opisania. Być może jest tak, iż pomimo nieustannego przyrostu wiedzy oraz dynamicznego rozwoju nauk (i nomotetycznych, i idiograficznych, by odwołać się do starego, XIX-wiecznego jeszcze podziału), a także dążeń uczonych - którzy próbują współpracować, przekraczając granice i wytyczając wspólne pole badawcze, eksplorowane z pasją przez przedstawicieli różnych dyscyplin - 
wiele obszarów pozostaje nieodkrytych albo wciąż, mimo usilnych starań, niepoznawalnych. Potrafimy, prawdopodobnie, mniej lub bardziej szczegółowo opisać różne typy pamięci oraz ich funkcjonowanie, znamy skuteczne techniki mnemoniczne (tu wciąż, bez względu na rozwój technologii, jesteśmy dłużnikami starożytnych), ale nie wiemy, jak zaradzić sytuacji, w której nie umiemy sobie czegoś przypomnieć. I dzieje się podobnie jak w wierszu Stycznie: 1990, 2003 z Odkrytek:

$\mathrm{w}$ tym tumanie $\mathrm{z}$ lat:

w mrozie który pod powieką

w ustach

już sobie siebie nie przypomnę,

[Latawiec 2007: 7]

kiedy staramy się „odpomnieć” samych siebie z innego czasu. Świadome, intencjonalne dążenie do anamnesis, „związane z aktywnym działaniem człowieka wspominającego przeszłość, który musi pokonać przeszkody, by uzyskać dostęp do umysłowej reprezentacji minionego doświadczenia" [Rydz 2011: 11], nie zawsze jednak okazuje się skuteczne, nawet jeśli, tak jak w wierszu Odpominanie z tomu Zmowy, podejmuje próby wielokrotnie, z nieustającym uporem:

Coraz częściej szukam

imion pierwszych, ostatnich

dat i miejsc

[...

Ale mozolne odliczanie czasu

na palcach obu rąk

[...]

z wolna traci swój sens wyższy

Gubi się w dłoniach

by wracać już w mylnym początku 
$[\ldots]$

i w zupełnie nie moim

(jak się okazuje)

życiu.

[Latawiec 2015: 24]

W tym dojmującym wyznaniu czas także zyskuje materialność, choć pozostaje nieuchwytny i niewidzialny. Odliczanie go „na palcach” oraz gubienie (a więc również zgubienie rytmu wyliczeń, co wymusza rozpoczęcie czynności od nowa) przywodzi na myśl inne metafory oraz związki frazeologiczne, w których występuje czas, chociażby znane „czas przecieka przez palce”, „czas szybciej płynie”. Budzi też skojarzenia z odmierzającymi nici żywota z rzymskimi parkami bądź greckimi mojrami - prządkami ludzkiego losu. Odpominanie jest kolejnym wierszem, w którym bohaterka próbuje odnaleźć siebie samą i innych z przeszłości. To zestawianie niepasujących do siebie obrazów, to nieustanne pytania o to, kim byłam i kim jestem, a także o ciągłość i zmianę nie tylko $\mathrm{w}$ indywidualnym wymiarze, choć doświadczenie osobiste, prywatne oraz intymne okazuje się tutaj najbardziej widoczne.

Czas wkracza też w pisanie wierszy, co dostrzec można nie tylko w lirykach, w których podejmuje się refleksję nad samym aktem twórczym i procesem pisania, ale też tych, w których poszukuje się minionego czasu: własnego dzieciństwa, dawnego „ja”. Znajduje to wyraz między innymi w utworach znanych $\mathrm{w}$ kilku wersjach, powstałych niekiedy na przestrzeni kilku [por. Latawiec 2007: 40; 2011: 21], a nawet kilkudziesięciu lat [por. Latawiec 1975: 21; 2015: 37]. Zdarza się bowiem, że autorka Catego drzewa zdania „Po prapremierze kolejnego wiersza wraca do niego, poprawia, nowe fragmenty wplątuje w nowe zwoje śladów długopisu. A może to wiersz wraca do niej? Po godzinie, po tygodniu, po latach..." [Balcerzan 2012: 180]. Otwiera to możliwość odczytywania obu wersji, ich porównywania, a także - co równie istotne - postawienia pytań o funkcje wprowadzonych zmian i miejsce wiersza $\mathrm{w}$ danym tomie. Pozwala to prześledzić (na poziomie wyższym od pojedynczego tekstu) nie tylko powta- 
rzalność pewnych wątków, ale też ich odautorskie modyfikacjęe. I tak Dzierlatka z Odkrytek oraz Dzierlatka (2) wspólny mają jedynie początek:

\author{
W ciasnocie snu, pamięci \\ nadal jesteśmy razem \\ choć ona to już nie ja \\ ja nie ona,
}

[Latawiec 2007: 40; por. 2011: 21]

po to, by się później odpodobnić: $\mathrm{w}$ konstrukcji liryku i w treści poszczególnych wersów. W Odkrytkach jest, w przedostatniej linijce, „czas miniony”, w Zmowach, w wyniku znaczącego uzupelnienia, pojawia się „kłębek (czasu)” i dzierlatka „po kostki w złotoskórym piasku / wprost ze słońca biegnąca". Czas - postrzegany linearnie - ponownie jawi się jak nić, po której można powrócić do przeszłości. Jednak młoda dziewczyna - ze snu oraz wspomnień nie słucha; przynależy do innego świata i innego czasu, chociaż, paradoksalnie, przynależy jako jedno z odsłon „ja” do osoby snującej tę anamnestyczną opowieść.

Metafora nici, tkania, zszywania pojawia się u Latawiec dość często: niekiedy w zaskakujących zestawieniach, niespodziewanej dla czytelnika interferencji obrazów i budujących nowe znaczenia współbrzmień, rymów, rytmów. W wierszu Pod stopa

2 Ta kwestia pozostawała dotąd na uboczu, choć bez wątpienia warto zapytać o rolę i znaczenie takich przekształceń w tej twórczości; ujawnia się w nich bowiem nie tylko samoświadomość Latawiec jako poetki, ale także sposób kształtowania słowa, pracy w języku - a więc kwestie niebywale interesujące zarówno dla teoretyka literatury, jak i dla poetologa, zwłaszcza takiego, dla którego punktem wyjścia do rozważań, nawet tych o charakterze metapoetyckim, będzie każdorazowo konkretny utwór. Nie oznacza to bynajmniej, że wprowadzam ostrą linię podziału między miłośnikiem poetyki opisowej i historycznej, z zapałem czytającym wiersze, a teoretykiem literatury. Wręcz przeciwnie. Praktyka analityczna oraz interpretacyjna zawsze są bowiem w znaczący sposób powiązane z metodą badawczą, teorią (teoriami), wreszcie - metodologią. To splot istotny, choć niekoniecznie nierozerwalny - można wszak z powodzeniem zajmować się rozważaniami metateoretycznymi, a nawet przemianami metodologii w obrębie nauk humanistycznych ( w tym - w literaturoznawstwie). 
Życie potyka się o ziemię

o kładkę

nad źródłem

\title{
Ci wiedzący
}

gdzie pamięć się kończy

i jakimi igłami porastają lasy

jakie szycie się tam odbywa

nie do zszycia - milczą.

[Latawiec 2015: 16]

Gra dźwięków, ich wyciszonej, choć silnie słyszalnej zbieżności (życie - poszycie lasu, życie - szycie igłami z igliwia, nie do zszycia - z życia), ma nie tylko walor instrumentacji głoskowej. Wraz z kolejną całostką utworu buduje bowiem metafory, którym oprócz funkcji poetyckiej i obrazotwórczej przypisać można wartość heurystyczną ${ }^{3}$, ponieważ dotyczą one mechanizmów działania ludzkiej pamięci: jako na poły żywej (jak leśne poszycie) tkaniny, z początkiem, lecz bez końca, z udziałem świadomości i tego, co zapamiętane nieświadomie, choć nieustannie, milcząco obecne. Wielość zdarzeń oraz natłok bodźców powodują, że przy próbie retrospekcji i opisania kolei własnego życia „zszywamy” różne jego fragmenty, tak, by stanowiły jednolitą, spójną całość, łapiemy i łączymy (a czasem gubimy) rozmaite wątki, starając się w tej sieci odnaleźć oraz scalić nas samych, dawnych i obecnych:

\author{
Czas się kolebie od łodzi do łodzi \\ nić, trop, sieć zarzucona \\ ale gdy nią łowić \\ tylko światło bezkrwiste \\ zamiast mięsa ryby \\ zostaje w dłoniach
}

3 Na temat metafor objaśniających w różny sposób funkcjonowanie pamięci pisał także Douwe Draaisma [2009: 32-39]. Szczególnie interesujący w tym kontekście jest jego opis pamięci jako maszyny tkackiej, którą odnajdziemy między innymi w pismach Kartezjusza. 
A w dole kładka do przebiegnięcia (wciąż ta sama)

ponad źródłem (którego nie ma)

choć je słyszę i słyszę

pod stopą.

[Latawiec 2015: 16]

Wielozmysłowe, synestetyczne doznawanie rzeczywistości nie stanowi jednak gwarancji przywołania (celowego) wspomnień, choć zdarza się, że jakiś pojedynczy impuls (na przykład zapach aktywujący pamięć węchową silnie związaną z emocjami) doprowadza do ożywienia tego, co minione, jak choćby w wierszu Proszę o zielone - dzieci stawiają tu w zeszytach pierwsze litery, tak

jakbyśmy sadzili drzewka

$\mathrm{z}$ bryłą korzeni $[\ldots]$

$\mathrm{z}$ nadzieją na listki życia.

[Latawiec 2015: 10]

Romantyczno-leśmianowskiej filozofii przyrody, o której pisze Piotr Michałowski [por. 2015: 66], towarzyszy jednocześnie (czy z ducha Przybosiowe?) przekonanie, że żyje się jednocześnie „na światy dwa”: ten zapisany (zapisywany) oraz bezpośrednio doświadczany, umykający nam z każdą sekundą. Tak podwójnie istnieje przecież tytułowy Kwiat nieznany, który

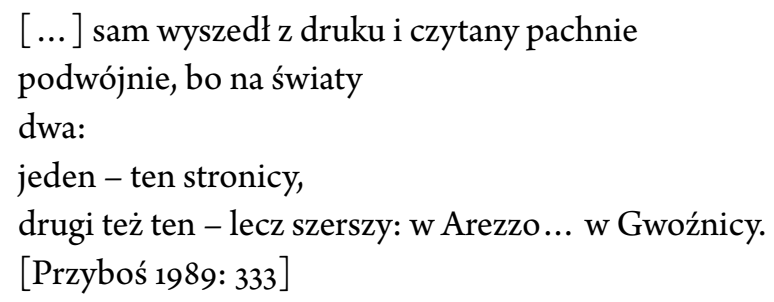

Także w tekstach Latawiec, którą bez wątpienia można uznać za jedną z uczennic Przybosia [por. Węgrzyniak 2002], istnieje stałe napięcie pomiędzy przeżyciem i związanym z nim konkretnym miejscem (subiektywnie istotnym na autobiograficznej mapie) a rozmaitymi sposobami ich lirycznej artykulacji, bez względu na 
to, czy dotyczą realnie widzianego czy już wspominanego obrazu (czasem zaś zdarzenia, a nawet procesu), który rekonstruuje się w całkowicie odmiennej materii: myśli, słowie, języku. Pisał o tym między innymi Balcerzan [2012: 181], wyjawiając czytelnikom:

W jej poezji rozpoznaję wiele rzeczywistych miejsc i zdarzeń, które przytrafily się i jej i mnie, a przecież nigdy nie potrafię zgadnąć, jak te realia wykorzysta, którędy poprowadzi rekonstrukcję faktu, a którędy wprowadzi zmyślenie. Więc za każdym razem od nowa przeżywam jej świat poetycki jako rozpoznawalny i nieprzewidywalny jednocześnie.

W Zdaniach pierwszych pojawia się nie tylko pytanie o relacje światów rzeczywistych, myślanych oraz pisanych:

Rzeka bez dna i bez brzegów

Można ją pomyśleć, ale zobaczyć?

Przejść?

[Latawiec 2015: 28]

i próba jasnego oddzielenia èikon (obrazu) od phantasma (wyobrażenia), ale też pełne obaw (potem zaś nadziei) wyznanie:

Wierzyłam, że pisząc wystarczy trwanie z iluzji trwania powielić zamieniając żywe życie na piórowe błyski głosek

[...]

I dobrze, niech tam w ciemności w zimie po zimach zimują może złapią oddech i poderwą się do lotu niczym rój nad polem z pełnoziarnistych zdań pierwszych ${ }^{4}$.

[Latawiec 2015: 28]

4 W jednym z programowych wierszy Przybosia [1989: 293], Więcej o manifest, pojawia się natomiast fragment, w którym także występuje metafora pisania 
Zegarowy świat zawiera natomiast przejmujący, liryczny opis prób „ożywiania” przeszłości (wraz ze znaczącym zwrotem aż do lat dziecinnych), w których aktywność podmiotu napotyka niemożliwe w danej chwili do pokonania przeszkody. Pomimo silnego, realnego pragnienia dotarcia do tego, co było (myślą, w wyobraźni, ale i na planie poetyckiego języka), oraz koncentracji na procesie wspominania (przypominania? „odpominania”?) zapoczątkowanego przez doznanie zmysłowe (zarówno realne, jak i wyśnione?), zamiast świetlistego rozpoznania pojawia się odczucie zagubienia:

1.

Kropla deszczu z rzęsitego snu

uniesiona do ust

porwała do lotu skrzydło łąki

sprzed dziesięcioleci

$[\ldots]$

2.

Zabłądziliśmy jak ptaki nieloty

w czasie zamiast w lesie

i nie pomogło nam nawet

białe światło

udzierganego w dzieciństwie szalika

bo polany bijąc o polany

tak się rozkrzewiły, rozdzwonity

że zwierzęta (te sierściste a nie skrzydlate)

uciekając

ginęły nam w oczach po kolei jak płowe pochodnie

aż ciebie od siebie zgubiłam

w tym zegarowym świecie

bez wyjścia i wejścia.

[Latawiec 2015: 32-33]

i zasiewu, związku życia i tworzenia, dziania się i utrwalania: „- Poeto krajobrazu, czy mógłbyś przedłużyć / dukt pióra na siewny rozmach / garści pełnej ziarna? / (Pytałem, a on, zamiast odpowiedzi, / z maszyny do pisania zrobił siewnik maczku”. 
To jednak nie tylko wiersz o pamiętaniu i wspominaniu, o wspomnieniach dobrych i złych, o zachwycie i lęku, ale także o miłości, dziejącej się w Zegarowym świecie, świecie Zegarów nie do zatrzymania [Latawiec 2012], w którym pielęgnuje się uczucia, przyjaźnie oraz współdzieli fascynację literaturą, refleksje z lektury, myśli i emocje, wzbudzane przez słowo mówione i pisane. Poezja, pisanie, ścisły związek z literaturą oraz twórcami wielkiego formatu ${ }^{5}$ stanowią istotną część życia i wyraźnie budują jedną $\mathrm{z}$ trzech, widzianych z perspektywy wielu lat, dróg życia: bogatego, wielowątkowego, trudnego do zamknięcia w jednoliniowej, pozornie tylko oczywistej, wspomnieniowej narracji.

Podwójność nie dotyczy tu wyłącznie otaczającego nas świata rzeczywistego oraz tego odtwarzanego i kreowanego w szeroko rozumianej twórczości artystycznej (o tym, że nie chodzi jedynie o sztukę słowa, przekonuje nas liryk Tylko czwarta, a z cyklu Blejtram następnych utwory Ostatni Rembrandt i Światy Caravaggia [Latawiec 2015: 44, 45]). Stanowi ona bowiem istotną właściwość każdego z tych światów i wykracza - poza prostą odpowiedniość - w dzianie się, proces wpisany w przemienność cyklicznie odnawialnej, ale też zmienianej przez człowieka natury, staje się wychyleniem w przyszłość i przeszłość, odejścia i powroty, świat i jego znak. Jest więc Wszystko podwojone, bo

\section{Po dziesięcioleciach}

stoki wymieniły się roślinami

i nawet pamięcią korzeni

$[\ldots]$ ziemia $\mathrm{z}$ niebem na nizinie

niebo z ziemią na wyżynie.

I podobnie dalej:

Jest więc $\mathrm{z}$ wędrowaniem

o czasie po czasie

5 O tych, jakże ważnych, spotkaniach i korespondencji, które chciałoby się zachować jak najdłużej w „żywej” pamięci, a nie tylko na zapisanych niegdyś odręcznie kartach papieru, poddanych współczesnym wymogom reprodukcji i typografii, przeczytać można między innymi w znajdującym się w Zmowach wierszu Listy. 
jak z życiem - wszystko podwojone

raz bliskie, raz obce

pod stopą, w oczach, na sercu.

[Latawiec 2015: 13]

Podwójność to również czytelny sygnał nawiązania do wydanego w języku włoskim wspólnego tomu wierszy Latawiec i Balcerzana, zatytułowanego Il tempo raddoppiato (Czas podwojony, 2011), w którym widać, jak splatają się ze sobą ich twórczość i życie po brzegi wypełnione poezją, odnajdowaną w najprostszym nawet słowie czy geście. Gdy jesteśmy sobą oraz jesteśmy „podwojeni” może zdarzyć się cud zatrzymania we wspólnie przeżywanej chwili nieuchronnie mijającego czasu:

Kładę dłoń na twojej twarzy

i świat się przesuwa pod palcami

ze świergotem taśmy za taśmą

Jesteśmy podwojoną przez sen smugą cienia wędrującą między uginającymi się u piaszczystego dna wodorostami i błyskiem tuż nad taflą

Płyniemy w źrenicach wody i pod moimi powiekami a ty wciąż powtarzasz coraz głośniej

otwórz oczy

otwórz je wreszcie!

czy ty mnie jeszcze widzisz?

jakby czas nie wędrował tylko trwał w tej rwącej fali niczym kłąb bursztynu na morskim dnie.

[Latawiec 2015: 31] 


\section{Bibliografia}

Balcerzan Edward (2012), Razem tu koncertujemy. O poezji Bogustawy, „Akcent”, nr 2, s. 180-183.

Balcerzan Edward, Latawiec Bogusława (2011), Il tempo raddoppiato, a cura di Andrea Ceccherelii, Lorenzo Costantino, nota introduttiva Jarosław Mikołajewski, Lithos Editrice, Roma.

Delaperrière Maria (2006), Pod znakiem antynomii. Studia i szkice o polskiej literaturze XX wieku, TAiwPN Universitas, Kraków.

Dembińska-Pawelec Joanna (2010), „Poezja jest sztuka rytmu”. O świadomości rytmu w poezji polskiej dwudziestego wieku (MiłoszRymkiewicz - Barańczak), Wydawnictwo Uniwersytetu Śląskiego, Katowice.

Draaisma Douwe (2006), Dlaczego życie płynie szybciej, gdy się starzejemy. O pamięci autobiograficznej, przeł. Ewa Jusewicz-Katler, PIw, Warszawa.

Grądziel-Wójcik Joanna, Łuszczykiewicz Piotr (2016), Bogusława Latawiec - portret podwojony, Pasaże, Kraków.

Draaisma Douwe (2009), Machina metafor: historia pamięci, przeł. Robert Pucek, Wydawnictwo Aletheia, Warszawa.

Draaisma Douwe (2012), Księga zapominania, przeł. Robert Pucek, Wydawnictwo Aletheia, Warszawa.

Hall Edward Terence (1999), Taniec życia. Inny wymiar czasu, przeł. Radosław Nowakowski, Muza, Warszawa.

Jakubowska-Ożóg Alicja (2012), Krokw krok za życiem, „Fraza”, nr 3, s. 276-278.

Latawiec Bogusława (1965), Otwierają się rzeki, Wydawnictwo Poznańskie, Poznań.

Latawiec Bogusława (1970), Całe drzewo zdania, pIw, Warszawa.

Latawiec Bogusława (1975), Przestrzenie, Wydawnictwo Poznańskie, Poznań.

Latawiec Bogusława (1989), Ciemnia, Wydawnictwo Pomost, Warszawa. Latawiec Bogusława (2001), Gęstwina, Wydawnictwo Książkowe Twój Styl, Warszawa.

Latawiec Bogusława (2003), Kochana Maryniuchna, Iskry, Warszawa. Latawiec Bogusława (2007), Odkrytki, PIw, Warszawa.

Latawiec Bogusława (2011), Gdyby czas byt ziemia, Biblioteka „Toposu”, Sopot.

Latawiec Bogusława (2012), Zegary nie do zatrzymania. Literackie portrety, listy, szkice, Instytut Mikołowski, Mikołów.

Latawiec Bogusława (2015), Zmowy, Wydawnictwo Forma, Fundacja Literatury imienia Henryka Berezy, Szczecin. 
Legeżyńska Anna (1990), Proust i stan wojenny, „Twórczość”, nr 11, s. $113-116$.

Maruszewski Tomasz (2005), Pamięć autobiograficzna, Gdańskie Wydawnictwo Psychologiczne, Gdańsk.

Merleau-Ponty Maurice (1976), Proza świata. Eseje o mowie, przeł. Ewa Bieńkowska, Stanisław Cichowicz, Joanna Skoczylas, wybór i wstęp Stanisław Cichowicz, Czytelnik, Warszawa.

Merleau-Ponty Maurice (2001), Fenomenologia percepcji, przeł. Małgorzata Kowalska, Jacek Migasiński, posł. Jacek Migasiński, Fundacja Aletheia, Warszawa.

Michałowski Piotr (1999), Zwierzęta nocy w ogrodach dnia, „Pogranicza”, nr 6, s. 81-83.

Michałowski Piotr (2015), Próby przestrzeni w grze na czas, w: Bogusława Latawiec, Zmowy, Wydawnictwo Forma, Fundacja Literatury imienia Henryka Berezy, Szczecin, s. 66-68.

Pound Ezra (1981), ABC czytania, „Teksty”, nr 3, s. 161-179.

Przyboś Julian (1989), Sytuacje liryczne. Wybór poezji, wstęp Edward Balcerzan, wybór Edward Balcerzan, Anna Legeżyńska, oprac. Anna Legeżyńska, Zakład Narodowy im. Ossolińskich, Wrocław.

Ricoeur Paul (2003), O sobie samym jako innym, przeł. Bogdan Chełstowski, oprac. i wstęp Małgorzata Kowalska, Wydawnictwo Naukowe PwN, Warszawa.

Ricoeur Paul (2008), Czas i opowieść, przeł. Małgorzata Frankiewicz, Jarosław Jakubowski, Urszula Zbrzeźniak, t. 1-3, Wydawnictwo Uniwersytetu Jagiellońskiego, Kraków.

Rydz Agnieszka (2011), Mnemozyna. O pamięci autobiograficznej w poezji polskiej, Wydawnictwo Naukowe UAM, Poznań.

Toadvine Ted (2014), Tempo naturale e natura immemoriale, transl. by Roberto Brigati, „Discipline Filosofiche”, no. 2, pp. 10-21 Węgrzyniak Anna (2002), Uczennice Przybosia, w: Stulecie Przybosia, red. Stanisław Balbus, Edward Balcerzan, Wydawnictwo Naukowe UAM, Poznań, s. 177-19o.

Zajączkowski Andrzej (1988), Czas Afryki czarnej, w: Czas w kulturze, wybór, oprac. i wstęp Andrzej Zajączkowski, pIw, Warszawa, s. $15-46$. 
Małgorzata Rygielska

Rhythms of time, the meanders of memory. On the poetry of Bogusława Latawiec

This paper deals with the problems of time and temporality in the poetry of Bogusława Latawiec ranging from one of her first volumes of poetry (Przestrzenie [Spaces], 1975) to the recently released Zmowy [Collusions] (2015). The passage of time, various ways of perceiving and sensing it are the overarching themes of her oeuvre (both prose and poetry). Her poetry, characterized by a remarkable linguistic discipline, a skillful use of formal devices and a close connection between the images and the sonic layer of her poems, highlights the importance of linking the experience of time and its passage with the issues of subjectivity and identity. Personal time converges here with historical, physical and mechanical time. It gains a material dimension: it becomes measurable and even tangible. This is noticeable in the poet's latest minor volumes: Gdyby czas byt ziemia [If time was the Earth] (2011) and in Zmowy [Collusions] (2015).

Keywords: time; temporality; memory; contemporary poetry; time in contemporary poetry.

Małgorzata Rygielska - adiunkt w Zakładzie Teorii i Historii Kultury Instytutu Nauk o Kulturze i Studiów Interdyscyplinarnych Uniwersytetu Śląskiego. Autorka książek: Dwa guziki. Norwid i ewolucjonizm (2011) oraz Przyboś czyta Norwida (2012). Współredaktorka tomów zbiorowych: Ciało. Granice. Kanon (wraz z Józefem Olejniczakiem, 2008), Starość jako wyobrażenie kulturowe (wraz z Anną Gomółą, 2013). Publikowała m.in. w „Ludzie”, „Kulturze Współczesnej”, „Kulturze Popularnej”, „Twórczości”, „Akcencie”, „Studiach Norwidianach”, „Zagadnieniach Rodzajów Literackich”. Interesuje się historią oraz teorią kultury, antropologią literatury w Polsce i na świecie, a także poezją polską dawną i współczesną. Kontakt: malgorzata.rygielska@us.edu.pl, malgorzata.rygielska@gmail.com. 